\title{
Peran Indonesia dalam Upaya Penyelesaian Konflik antara Pemerintah Filipina dan Moro Nationalism Liberation Front (MNLF)
}

\author{
Hardi Alunaza SD \\ Dewa Anggara \\ Universitas Tanjungpura
}

\begin{abstract}
The Moro Nationalism Liberation Front (MNLF) has long been perceived by the Philippine government as a threat. The continuity of this conflict resulted in the instability of the Philippine state which also affects its relations with other countries. Indonesia as a neighboring country and one region with the Philippines helped to resolve the conflict between the Philippine government and MNLF. The presence of Indonesia became a history of Indonesian diplomacy for the world peace struggle contained in Indonesia's Preamble of the 1945 Constitution. This paper is attempts to answer that question using conflict theory from Max Weber which focuses on interaction in conflict resolution. The results of this paper indicates that Indonesian's role in mediating the conflict resolution process resulted in a Final Peace Agreement which is the final peace agreement between the Philippine Government and MNLF.
\end{abstract}

Keywords: Moro Nationalism Liberation Front (MNLF), Philippine, Indonesia, conflict resolution, Final Peace Agreement, mediation

\begin{abstract}
Abstrak
Moro Nationalism Liberation Front (MNLF) telah lama dianggap pemerintah Filipina sebagai ancaman. Kontinuitas dari konflik ini mengakibatkan ketidakstabilan negara Filipina yang juga mempangaruhi hubungannya dengan negara lain. Indonesia sebagai negara tetangga dan satu kawasan dengan Filipina ikut membantu upaya penyelesaian konflik yang terjadi antara Pemerintah Filipina dengan MNLF. Kehadiran Indonesia menjadi sebuah sejarah diplomasi Indonesia bagi perjuangan perdamaian dunia yang termuat dalam Pembukaan UndangUndang Dasar 1945. Tulisan ini berusaha untuk menjawab pertanyaan tersebut dengan menggunakan teori konflik dari Max Weberyang berfokus pada interaksi dalam penyelesaian konflik. Hasil dari tulisan ini menunjukkan bahwa, peran Indonesia dalam menengahi upaya penyelesaian konflik menghasilkan sebuah Final Peace Agreement yang merupakan perjanjian akhir perdamaian antara Pemerintah Filipina dengan MNLF.
\end{abstract}

Kata-kata kunci: Moro Nationalism Liberation Front (MNLF), Filipina, Indonesia, resolusi konflik, Final Peace Agreement, mediasi 


\section{Pendahuluan}

Kelompok Muslim Moro mendiami wilayah yang tercakup dalam 13 propinsi yang berada di bawah Undang-Undang Empat Zona yang berbeda-beda yaitu: pertama, masuk dalam zona IV ada gugusan pulau Palawan; kedua, masuk dalam zona IX seperti pulau Sulu, Basilan, Tawi-Tawi, Zamboanga del Sure; ketiga, masuk dalam Zona XI tercakup didalamnya gugusan pulau Cotabato Selatan, Dan Davao del sure; sedangkan keempat, masuk dalam zona XII seperti Lanao del Norte, Lanao del Sure, Cotabato Utara, Maguindanao dan Sultan Kudarat (Abdullah, 1983: 341).

Persebaran penduduk muslim di Filipina Selatan atau Muslim Moro ini merupakan hasil dari sebuah kebijakan yang dibuat oleh pemerintah Filipina dengan tujuan untuk mengetahui demografi dan persebaran penduduk di Filipina. Dalam sejarahnya, bangsa Spanyol pernah datang ke Filipina untuk berdagang dan melakukan ekspedisi bersejarah yang salah satunya dipimpin oleh Ferdinand Magellan. Kedatangan bangsa Spanyol ini merupakan awal dari terusiknya struktur budaya dan agama masyarakat Muslim di wilayah Filipina, khusunya Filipina Selatan.

Kesultanan Sulu dan Mindanao yang berdiri di wilayah Filipina Selatan memberikan perlawanan terhadap kedatangan bangsa Spanyol. Sehingga dalam sejarahnya pemberontakan di Filipina Selatan memiliki riwayat permusuhan yang panjang karena konstruksi social yang menimbulkan bibit kebencian di dalam masyarakat muslim Filipina. Benih kebencian itu rupanya tidak hilang melalui perjalanan waktu, bahkan makin bertambah. Kurangnya kesadaran sejarah telah menyebabkan kaum Moro tidak mampu mencari jalan keluar dari kemunduran yang telah lama mereka derita (Yatim, 1985: 130). Karena terdapat kebencian yang berakar dari sejarah, masyarakat Muslim Filipina di bagian selatan terus bertahan untuk memisahkan diri dari wilayah administratif Filipina yang berada di bawah pendudukan Spanyol.

Wilayah masyarakat Muslim di Selatan baru bisa bersatu secara bertahap dengan rakyat Filipina lainnya setelah negara itu diduduki Amerika Serikat selama masa Perang Dunia II. Pada masa kekuasaan Amerika Serikat kaum Muslim kehilangan kontrol atas wilayah Filipina Selatan (Steinberg, 1990: 88). Namun Amerika Serikat tidak menunjukan usaha untuk memperbaiki kondisi sosial budaya masyarakat Muslim Filipina. Sebaliknya Amerika Serikat semakin memperburuk kondisi dengan memasukkan wilayah Kesultanan Sulu dan Mindanao sebagai bagian dari wilayah administratif Filipina saat diberikan kemerdekaan oleh Amerika Serikat. Hal ini memicu pemberontakan yang dilakukan oleh masyarakat Muslim Filipina, khususnya di bagian selatan yang biasa dikenal dengan Bangsa Moro.

Setelah Filipina mendapatkan kemerdekaan pada tahun 1946, 
keadaan masyarakat Muslim di Filipina di bagian selatan yaitu di Sulu dan Mindanao tidak mengalami perubahan signifikan yang mengarah pada kestabilan kondisi sosial budaya dan politik di Filipina. Bangsa Moro yang merupakan penduduk minoritas yang beragama Islam merasakan bahwa tidak ada usaha dari pemerintah Filipina untuk mengakomodasi kepentingan masyarakat Muslim di Filipina, yaitu ditandai dengan kejenuhan umat Muslim di Filipina yang selalu saja terpinggirkan sejak proses Kristenisasi di tahun 1940 setelah Filipina mendapatkan kemerdekaan dari Amerika Serikat (Mudler, 2005: 29-30). Proses Kristenisasi ini seakan-akan terlihat seperti ketidaksukaan pemerintah Filipina terhadap keberadaan Muslim Moro di Filipina.

Marginalisasi yang dilakukan secara kontinyu terhadap masyarakat Muslim di Filipina Selatan kemudian menyebabkan perlawanan terhadap pemerintah Filipina. Dalam mengatasi perlawanan dan pemberontakan yang dilakukan masyarakat Muslim Filipina, sebuah kebijakan dikeluarkan oleh pemerintah Filipina yaitu salah satunya dengan memberikan beasiswa dan prioritas pendidikan bagi masyarkaat Muslim Filipina. Namun hal itu justru memicu terbentuknya perlawanan yang bersifat terorganisir. Masyarakat Muslim menghadapi kenyataan bahwa adanya kesenjangan yang begitu besar antara penduduk Filipina yang mayoritas Katolik dengan masyarakat Muslim. Hal ini dirasakan oleh para penerima beasiswa dari pemerintah Filipina tersebut. Oleh karena itu mereka memanfaatkan kesempatan itu untuk menjadi kaum intelektual yang dapat menjadi pemimpin penggerak kebebasan masyarakat Muslim di Filipina.

Pada 1968 terjadi peristiwa pembantaian terhadap anak-anak muda Muslim di Pulau Corregidor atau lebih dikenal dengan Tragedi Jabidah. Tragedi Jabidah telah mengorbankan masyarakat Muslim Moro di Corregidor dan mendorong tokoh politik Islam Filipina bernama Nur Misuari untuk bangkit memperjuangkan nasib Muslim Moro melalui sebuah organisasi. Nur Misuari adalah pencetus berdirinya organisasi Moro National Liberation Front (MNLF) tahun 1971 (Chaidar, 1999: 39).

Dalam usaha perdamaian antara pemerintah Filipina dengan MNLF, Indonesia adalah salah satu yang berperan dalam usaha perdamaian yaitu dengan bertindak sebagai mediator. Selain sebagai sesama anggota ASEAN, Indonesia telah menjadi pihak yang mendapat pengakuan dari pemerintah Filipina terhadap kesamaan keadaan sosial budaya dan politik. Hal ini membuat pemerintah Filipina memiliki harapan bahwa Indonesia mampu memberikan solusi terhadap masalah di Filipina. Sementara itu, konflik semakin pelik karena Malaysia yang merupakan negara dengan mayoritas penduduk Muslim mendukung gerakan MNLF secara simbolik tanpa terlihat sebagai sebuah intervensi. Untuk mengatasi masalah tersebut, Ferdinand Marcos, presiden Filipina saat itu meminta bantuan kepada Presiden 
Suharto. Dari sinilah dimulainya peran Indonesia dalam upaya penyelesaian konflik antara Pemerintah Filipina dengan MNLF.

Artikel ini mempunyai tiga pokok bahasan. Pertama, hubungan politik Filipina dengan negara-negara tetangga di Asia Tenggara pada saat terjadinya konflik dengan MNLF. Kedua, kerjasama politik antara Filipina dan Indonesia. Ketiga, peran Indonesia dalam politik perdamaian antara pemerintah Filipina dengan MNLF.

\section{Konflik dan Resolusi Konflik: Sebuah Kerangka Konseptual}

Konflik memiliki tujuan ganda; tujuan integrasi dan tujuan pembebasan diri, gengsi dan kerusakan. Selain itu konflik juga bertujuan untuk memelihara proses, pengaturan organisasi dan solidaritas. Teori konflik Max Weber berorientasi lebih kepada stratifikasi dan perubahan sosial (Turner, 1991: 196). Teori Weber tentang konflik, dijelaskannya sebagai berikut:

Suatu hubungan sosial akan mengarah kepada konflik, sejauh merupakan tindakan intensional dan terorientasi, yang mendorong munculnya para aktor yang sepantasnya mendapat tantangan dan perlawanan dari pihak (kelompok/golongan) lain. Kegiatan individu-individu dalam mengambil posisi, atau jenis status sosial lain untuk memperoleh keuntungan dalam kehidupannya adalah sering bersifat laten atau tidak tampak, tetapi dengan orientasi untuk tidak saling memberi makna yang sama, maka ada dalam terminologi konflik (Eldridge, 1980: 85).

Menurut Weber suatu konflik terjadi dalam suatu hubungan sosial, sehingga konflik terjadi karena adanya interaksi antara para aktor yang berpotensi untuk berkonflik. Dengan demikian interaksi yang merupakan sumber konflik merupakan kunci dari pada penyelesaian konflik itu sendiri. Kemungkinan kedua pihak berkonflik yang terjadi karena interaksi berbanding sama dengan kemungkinan terjadinya harmoni sosial dengan cara berinterkasi. Jadi resolusi konflik ditempuh melalui interaksi yang harmonis antara kedua pihak yang berkonflik.

Dalam pendekatan tradisional, konflik secara umum adalah hal yang tidak dapat terhindarkan karena pengaruh dari lingkungan atau sistem atau struktur kehidupan yang anarki. Sehingga sebuah konflik akan selesai jika ada yang memenangkannya atau biasa disebut dengan zero-sum solution. Penyelesaian konflik dengan cara demikian hanya sekedar terlihat efektif, namun di balik penyelesaian tersebut hanya akan mendorong tin- 
dakan balas dendam dari pihak yang kalah terhadap pihak pemenang yang mengakibatkan kontinuitas konflik.

Melihat hal itu, Miall dan Haouse (2000: 7-33) menawarkan banyak alternatif tentang resolusi konflik, mulai dari pemikiran klasik sampai pada pemikiran kontemporer. Pemikiran resolusi konflik berangkat dari asumsi bahwa konflik sebagai aspek intrinsik yang tidak mungkin dihindarkan dari perubahan sosial. Konflik diartikan sebagai ekspresi heterogenitas kepentingan, nilai dan keyakinan yang muncul sebagai formasi baru yang ditimbulkan oleh perubahan sosial yang muncul bertentangan dengan berbagai hambatan yang dihasilkannya. Namun cara menangani konflik adalah persoalan kebiasaan dan pilihan, sehingga perlu merespon cara menangani konflik tersebut.

\section{Latar Belakang Konflik antara MNLF dan Pemerintah Filipina dan Upaya Perdamaian}

MNLF merupakan sebuah gerakan yang bersifat semi-radikal, dimana terbentuk karena adanya perasaan nasionalisme dalam sebuah komunitas yang terpinggirkan dan termarjinalkan oleh perubahan-perubahan yang bertentangan dengan nilai dan kepentingan mereka. Komunitas yang dimaksud adalah masyarakat Muslim Filipina di bagian selatan yang disebut dengan Bangsa Moro. Menurut Theodorson, gerakan ini merupakan sebuah gerakan sosial, sebab kebanyakan orang yang terlibat bersifat informal atau secara tidak langsung (Mubarok, 1993: 51).

MNLF adalah gerakan perlawanan yang dipimpin oleh Profesor Nur Misuari, seorang akademisi dari Universitas Filipina yang berupaya memisahkan diri dari Filipina sejak dekade 1970-an sebagai respon terhadap marjinalisasi yang dilakukan oleh pemerintah Filipina terhadap Bangsa Moro. Dalam perkembangannya, MNLF ini mengalami berbagai perubahan sikap yang merupakan respon terhadap perubahan-perubahan yang disebabkan oleh kebijakan-kebijakan pemerintah Filipina dalam setiap rezimnya masing-masing. Oleh karena itu, MNLF menjadi sebuah organisasi pergerakan yang melawan pemerintah Filipina atas dasar ketidakadilan yang dialami masyarakat Muslim Filipina, secara khusus di Kepulauan Sulu dan Mindanao.

Dalam konteks ideologis, MNLF mengidentifikasi diri dengan ideologi nasionalis-sekuler dibandingkan dengan ideologi Islam. Latar belakang dari Nur Misuari itu sendiri berpengaruh langsung terhadap pemilihan ideologi organisasi ini, yaitu dimana dia adalah seorang aktivis gerakan sosialis Islam selama masih mahasiswa. Bahkan Salamat Hashim yang merupakan wakilnya dan yang memisahkan diri dari MNLF dengan mendirikan Moro Islamic Liberation Front (MILF) menuduh Nur Misuari mengubah haluan ideologi organisasi menjadi gerakan dengan ideologi komunis (Majul, 1990: 230). 
Seiring berjalannya waktu MNLF juga ikut melakukan transformasi yang dipengaruhi oleh keadaan sosial politik di Filipina. Perundingan-perundingan yang mengarah pada perdamaian terus diusahakan oleh kedua belah pihak yang salah satunya tertuliskan dalam Perjanjian Tripoli yang fasilitasi oleh Libya, namun perjanjian ini tidak teraplikasikan dengan lancar karena banyaknya tafsiran dari kedua belah pihak yang pada dasarnya saling mencurigai, sehingga konflik terus terjadi dan membawa instabilitas dalam wilayah Filipina.

Pada masa Ferdinand Marcos menjadi presiden Filipina, pergerakan MNLF sangat masif untuk melawan kekerasan yang dilakukan oleh aparat pemerintah Filipina kepada masyarakat Muslim. Kekerasan ini dipandang oleh Nur Misuari sebagai wujud dari genosida, dimana masyarakat Muslim dibantai oleh tentara Ilaga Kristen bentukan pemerintah Filipina. MNLF tidak melakukan perlawanan langsung terhadap tentara Ilaga secara gerilya, namun mendukung gerakan-gerakan militan masyarakat Muslim.

Banyaknya korban jiwa dari kejahatan kemanusian terhadap masyarakat Muslim Filipina mendapat perhatian dari negara-negara anggota Organisasi Konferensi Islam (OKI), yaitu Libya, Malaysia, Indonesia, Arab Saudi, dan Yordania. Dari kerjasama OKI lahirlah sebuah perjanjian yang memperjuangkan perdamaian antara pemerintah Filipina dengan MNLF, yaitu Perjanjian Tripoli yang difasilitasi oleh Libya (Dardiri, 2006: 128). Perjanjian yang dilaksanakan mulai tanggal 23 Desember 1976 ini berisi penetapan prinsip-prinsip umum bagi otonomi Islam di Filipina Selatan. Pada intinya Tripoli Agreement 1976 menghasilkan dua hal pokok; pertama, pembentukan pemerintah otonomi di wilayah Filipina Selatan dalan lingkungan kedaulatan dan teritorial Filipina. Kedua, wilayah otonomi Muslim di Filipina Selatan meliputi: Basilan, Sulu, Tawi-Tawi, Zamboanga del Sur, Sultan Kudarat, Lanao del Norte, Lanao del Sur, Davao del Sur, South Cotabato, Palawan.

Ketika persetujuan disempurnakan, pihak pemerintah Filipina berusaha menghindar dari apa yang telah disepakati dan meningkatkan kegiatan sabotase terhadap pasukan Muslim. Hasilnya cukup mengecewakan MNLF karena dari 13 wilayah tersebut hanya empat yang bersedia bergabung (Firmanzah, 2017: 43). Selain itu kekecewaan dari MNLF juga terjadi karena pemerintah Filipina tidak merealisasikan perjanjian tersebut. Sebaliknya Presiden Marcos melakukan propaganda untuk menghancurkan MNLF. Sehingga dalam konteks upaya perdamaian, perjanjian ini dianggap telah gagal karena salah satu pihak tidak mengakuinya. Di samping itu, perjanjian yang tanpa pengawasan ini tidak efektif karena terjadi secara sepihak oleh MNLF dan bukan merupakan kebulatan suara demi mewujudkan perdamaian bersama yang mana kepentingan kedua pihak terakomodasi. Namun demikian, perjanjian ini penting sebagai batu loncatan bagi perjanjian perdamaian yang akan datang. 
Pada 1996 terjadi perubahan yang membawa kemajuan bagi masyarakat Muslim di Filipina, yaitu pergantian presiden dari Ferdinand Marcos kepada Corazon Aquino. Perubahan ini tentu saja diharapkan dapat membawa perdamaian di Filipina Selatan. Seperti yang diharapkan, selama pemerintahan Aquino pemerintah Filipina cenderung membuat kebijakan akomodatif terhadap kelompok perlawanan Mindanao daripada kebijakan refresif. Pilihan kebijakan ini tidak bisa dilepaskan dari spektrum politik di Filipina dan dukungan internasional untuk menyelesaikan konflik Mindanao di meja perundingan (Firmanzah, 2017: 44).

Aquino membangun formula dengan menerjemahkan perjanjian damai ke dalam bentuk undang-undang, yaitu Organic Arc on Autonomy for Muslim Mindanao yang kemudian dimasukkan kedalam perubahan Konstitusi 1987 dengan nama Autonomos Region in Muslim Mindanao (Firmanzah, 2017: 45). Upaya baru ini tentu saja memberikan kabar baik bagi Nur Misuari yang sebelumnya kecewa terhadap pelaksanaan Perjanjian Tripoli. Alhasil, selama pemerintahan Aquino Nur Misuari kembali melihat adanya kesempatan dan menjadi babak baru untuk mewujudkan cita-cita perdamaian di Filipina Selatan.

Namun, kebijakan yang dikeluarkan oleh Aquino tersebut dalam prosesnya ditentang oleh Nur Misuari karena bertentangan dengan Perjanjian Tripoli dan dianggap merugikan pihak MNLF. MNLF menganggap bahwa pelaksanaan perjanjian tersebut tidak adil sehingga mengundang kemarahan sebagian sayap MNLF dan tingginya perlawanan MILF. Akibatnya, ketegangan dan kekerasan pun kembali meningkat. Presiden Fidel Ramos yang menggantikan Aquino pada 1993 mencoba kembali merintis pembicaraan dengan MNLF dengan menjanjikan mengembalikan wilayah yang ada di dalam Perjanjian Tripoli dengan memasukan klausul terpenting pada Final Peace Agreement yang ditandatangani di Jakarta pada 2 September 1996 yang bunyinya, "the Final peace agrrement constitutes the full implementasi of the Tripoli Agreement"(Frimanzah, 2017: 45).

\section{Hubungan Filipina dan Negara di Asia Tenggara dan Implikasinya terh- adap Konflik Filipina-MNLF}

Setelah berdirinya MNLF, Presiden Ferdinand Marcos menanggapi gerakan MNLF dan berbagai perlawanan Muslim di Mindanao dianggap sebagai pemberontak dengan memberlakukan Martial Law atau keadaan darurat perang pada tahun 1972. Ia mengirim tentara besar-besaran ke Mindanao untuk menumpas pemberontakan dan tuntutan merdeka yang mulai membesar. Reaksi keras dari presiden Marcos justru semakin menguatkan dukungan dari Bangsa Moro untuk MNLF (Firmanzah, 2017: 40).

Sadar dengan dampak negatif permusuhan itu terhadap kestabilan politik, pemerintah Filipina melakukan peningkatan hubungan diploma- 
tik dengan negara-negara di Asia Tenggara yang tergabung dalam ASEAN. Filipina adalah salah satu pelopor ASEAN sehingga Filipina memiliki akses hubungan kerjasama dengan negara-negara pelopor lainnya, seperti Indonesia, Malaysia, Singgapura, dan Thailand. Keberadaan Indonesia dan Malaysia sebagai negara dengan penduduk mayoritas Muslim membuat Filipina merasakan perlunya hubungan politik yang kuat antarnegara tersebut sehingga dapat dimanfaatkan untuk penyelesaian konflik di Filipina Selatan (Wurfel, 1991: 46).

Melalui hubungan politik Filipina dengan negara-negara tetangga, Filipina mampu membangun kembali hubungan yang sebelumnya renggang dengan Malaysia. Dalam konteks konflik MNLF-pemerintah Filipina, Malaysia mendukung gerakan masyarakat Muslim di Filipina Selatan. Hubungan yang baik dengan Malaysia memberi harapan meminimalisasi suplai persenjataan terhadap MNLF. Memperluas hubungan dengan dunia Muslim juga termasuk dalam strategi politik yang dilakukan oleh pemerintah Filipina untuk memperlemah moral pasukan MNLF. Pada tahun 1975 Filipina mengirim delegasinya untuk mengikuti konferensi di Arab dan dalam kesempatan itu pemerintah Filipina menawarkan otonomi Muslim di Mindanao dan Sulu sebagai bentuk upaya meredam konflik. Hasilnya adalah munculnya penawaran dari Yordania untuk melakukan pertukaran duta besar dengan Filipina sebagai wujud pengakuan terhadap niat pemerintah Filipina sekaligus perwakilan untuk mengawasi implementasi keputusan-keputusan OKI (Wurfel, 1991: 46).

Pendekatan yang dilakukan oleh pemerintah Filipina terhadap negara-negara Muslim merupakan sebuah langkah untuk mewujudkan stabilitasi kawasan Filipina Selatan, yang mana konflik antara pemerintah Filipina dengan pejuang Moro belum menemukan titik terang bahkan setelah beberapa perjanjian perdamaian terbentuk. Namun, dengan adanya kerjasama antara Filipina dan negara-negara Muslim, salah satunya Yordania yang merupakan penyuplai bantuan terhadap pasukan pejuang Moro, akhirnya bantuan dari Yordania kepada pejuang Moro dihentikan (Gowing, 1979: 220).

Perubahan strategi politik yang dilakukan oleh pemerintah Filipina ini membuat militansi pejuang MNLF menurun karena kurangnya pasokan senjata dan bantuan logistik. Hal ini melemahkan kedudukan MNLF sebagai organisasi yang ingin mendirikan pemerintahan otonom di Filipina Selatan. Situasi ini membuka kesempatan bagi tentara Filipina untuk menekan kekuatan pejuang Moro dan mendesak para pejuang Moro dari wilayah pertempuran.

Selain memperkuat hubungan dengan Malaysia dan Yordania, Filipina juga memperkuat hubungan dengan Indonesia. Hubungan Indonesia-Filipina bermula dari terbentuknya organisasi Maphilindo yang meru- 
pakan organisasi dari tiga negara, yaitu Malaysia, Filipina, dan Indonesia. Namun dalam perkembangannya organisasi ini tidak berjalan baik dikarenakan gesekan kepentingan antarnegara anggota, khususnya Malaysia dengan Filipina dalam konflik Sabah. Permasalahan kedua negara tersebut semakin meningkat menjadi lebih buruk ketika Malaysia mulai memberikan dukungannya kepada MNLF sebagai perjuangan pembebasan Bangsa Moro. Akibatnya, pemerintah Filipina pada masa itu meminta bantuan Indonesia di bawah pemerintahan Presiden Suharto (Suryadinata, 1998: 103). Setelah itu hubungan kedua negara mulai membaik dan berkembang.

Dari sini dapat terlihat bagaimana Indonesia mengambil kesempatan dalam perpolitikan internasional yang berskala regional, dimana Indonesia memiliki daya tarik tersendiri dalam hal kepercayaan negara lain untuk menyelesaikan berbagai kasus-kasus rumit yang menyulitkan. Dari peran Indonesia dalam upaya pemulihan hubungan Malaysia-Filipina ini menghasilkan hubungan kerjasama bilateral yang sama-sama menguntungkan. Oleh karena itu Indonesia secara politik memiliki reputasi baik dalam menerapkan politik luar negerinya terhadap perkembangan politik internasional yang anarki.

Presiden Marcos meminta bantuan Indonesia mengenai upaya penyelesaian konflik Filipina-MNLF. Dari sinilah hubungan antara Indonesia dan Filipina yang bersifat politik mulai terjalin. Menanggapi permintaan negara tetangga tersebut, Presiden Suharto langsung memberikan respon sesuai dengan perspektifnya untuk mengatasi krisis di Filipina tersebut. Suharto mengajukan empat usul untuk mengatasi permasalahan Moro. Pertama, adanya jaminan bagi masyarakat Muslim di Filipina Selatan untuk menganut kepercayaan mereka dan mengembangkan kebudayaan mereka tanpa adanya pembatasan dari pemerintah yang melanggar HAM. Kedua, tradisi dan budaya Islam dihargai secara universal oleh keseluruhan Filipina. Ketiga, tanah-tanah nenek moyang Bangsa Moro dikembalikan kepada penduduk setempat. Keempat, Masyarakat Islam berkesempatan untuk berpartisipasi dalam pembangunan nasional di Filipina (Suryadinata, 1998: 104).

Namun, dari semua alternatif yang disampaikan oleh Suharto kepada pemerintah Filipina tersebut tidak secara bulat diterima. Pemerintah Filipina keberatan dengan opsi pengembalian tanah nenek moyang Bangsa Moro dan menolak usulan tersebut. Penolakan tersebut didasari argumen bahwa seluruh tanah tersebut hampir sebagian besar dikuasai oleh penduduk Kristen di Filipina Selatan yang membentuk komunitas mayoritas setelah adanya Kristenisasi yang dilakukan dari masa kolonial hingga kemerdekaan Filipina. Penolakan ini juga membuat kecewa Presiden Soekarno sehingga mempengaruhi hubungan kedua negara. Presiden Marcos pada akhirnya mengesampingkan usulan Indonesia dan beralih mendekati negara-negara Islam di Timur Tengah dan OKI. 
Dalam usaha perdamaian dan keamanan kawasan, sebagai sesama negara yang tergabung di dalam ASEAN, Indonesia tetap memberikan masukan-masukan yang sekiranya dapat mempengaruhi politik Filipina dalam menghadapai konflik Moro dengan politik konfrontatifnya. Indonesia juga membantu dalam menyelesaikan isu Sabah yang mana terjadi konflik antara Filipina d Malaysia. Usaha dalam menyelesaikan isu Sabah ini dibuktikan dengan upaya Presiden Soekarno untuk meyakinkan Marcos untuk melepas tuntutan Manila atas Sabah dalam rangka untuk mendorong solidaritas dalam ASEAN (Suryadinata, 1998: 105). Namun tindakan ini mendapat reaksi lain dari pihak Filipina; bahwa Indonesia terlalu mencampuri urusan dalam negeri Filipina. Sehingga hal ini mendorong friksi dalam hubungan Indonesia-Filipina. Hubungan kedua negara menjadi kurang akrab. Namun, hubungan Indonesia-Filipina tidak sebatas hubungan yang bersifat politik, sehingga tidak semua kerjasama dengan Filipina berujung kebuntuan.

Seiring berjalannya waktu, Filipina juga mengalami pergantian rezim yang membawa pengaruh terhadap perbaikan hubungan dengan Indonesia dan negara lainnya. Setelah Ferdinand Marcos digantikan oleh Corazon Aquino, banyak terjadi perubahan dalam segi politik luar negeri. Haluan politik yang dulunya konfrontatif berubah menjadi lebih akomodatif. Hal ini dibuktikan dengan kunjungan Aquino ke Indonesia yang menunjukan adanya hubungan dalam memperbaiki ikatan kerjasama. Dalam kunjungan tersubut banyak hal yang dibahas dan diskusikan antara Presiden Aquino dengan Presiden Suharto. Mulai dari masalah komunisme, isu Moro, dan hal-hal yang berkaitan dengan pembangunan ekonomi berkelanjutan kawasan antara Indonesia dan Filipina. Hubungan baik ini terus berlanjut hingga presiden Filipina selanjutnya yaitu Fidel Ramos. Hal ini karena gaya kepemimpinan dua presiden tersebut tergolong sama. Bukti hubungan baik antara Indonesia dan Filipina adalah tetap dilanjutkannya bantuan dari Indonesia kepada Filipina yang merupakan wujud dari kerjasama yang sebelumnya sudah terjalin (Suryadinata, 1998: 108).

Dinamika hubungan antara Indonesia dan Filipina yang dipengaruhi oleh perubahan rezim ini menunjukan bahwa konteks politik domestic merupakan hal vital dalam mempengaruhi hubungan antarnegara. Terjalinnya kerjasama antara Indonesia dan Filipina adalah sebuah bentuk dari kehidupan dalam struktur politik internasional yang mengharuskan setiap negara untuk saling berinteraksi satu sama lain dalam pemenuhan kebutuhan nasionalnya. Untuk menjaga stabilitas nasional suatu negara dapat dilakukan dengan negosiasi atau menggunakan jasa baik dari negara lain sebagai mediator.

Keterlibatan Indonesia dalam permasalahan Moro di Filipina dimulai pada akhir 1990-an pada Konferensi Tingkat Menteri (KTM) OKI ke- 
20 di Istanbul, di mana Turki, Indonesia, dan Bangladesh masuk ke dalam Komite Enam. Pertemuan di Bogor, melalui Jakarta Informal Meeting I dan II dengan Indonesia sebagai interlocutor berhasil membantu upaya penyelesaian permasalahan-permasalahan di dalam negara-negara tetangga yang terjadi diskriminasi terhadap masyarakat minoritas Muslim, termasuk salah satunya kasus di Filipina Selatan (Rachmatsyah, 2016: 64-65). Keberhasilan dan prestasi Indonesia dalam memberikan landasan bagi upaya perdamaian di kawasan menjadi perhatian negara-negara anggota OKI yang kemudian menaruh kepercayaan kepada Indonesia dalam mengatasi kasus-kasus serupa, baik di kawasan Asia Tenggara maupun internasional. Sehingga hal ini juga mendukung Indonesia yang merupakan negara Muslim moderat terbesar di Asia Tenggara yang telah secara aktif mendukung perdamaian di dunia. Kemudian pada KTT OKI ke-21, Malaysia dan Brunei masuk ke dalam Komite Enam dan berubah nama menjadi Komite Delapan. Mulai saat itu hingga tahun 2013 Indonesia menjadi ketua komite (Rachmatsyah, 2016: 65).

Pada pertengahan 1990-an, Indonesia berkontribusi dalam upaya penyelesaian konflik Moro di Filipina. Pada saat itu pemerintah Indonesia di bawah pemerintahan Suharto menawarkan jasa baik untuk menengahi permasalahan yang rumit di Filipina Selatan. Tawaran tersebut direspon positif oleh Misuari sebagai ketua MNLF sentral pejuang Moro dan Presiden Ramos. Kesempatan itu telah menghasilkan perundingan yang memungkinkan perdamaian antara pemerintah Filipina dan MNLF. Adapun hasil dari pada perundingan tersebut adalah terbentuknya Final Peace Agreement pada 1966 sebagai bentuk perjanjian kedua yang menggantikan Perjanjian Tripoli. Perjanjian tersebut ditandatangani oleh kedua belah pihak yang bertikai sehingga bersifat mengikat dan sebagai pedoman perdamaian (Rachmatsyah, 2016: 66).

Kepercayaan yang diberikan kepada Indonesia untuk menjadi bagian dalam penyelesaian masalah di Filipina Selatan ini merupakan fakta sejarah bahwa Indonesia di Indonesia juga terdapat banyak kasus separatisme, yang memberikan Indonesia pengalaman dan pengetahuan lebih dalam untuk mengatasi masalah-masalah serupa. Dengan adanya pengalaman ini tentu belum cukup untuk meyakinkan kedua pihak yang bermasalah. Namun sikap dan prinsip Indonesia dalam penghormatan kepada keutuhan kedaulatan nasional Filipina merupakan hal yang mempengaruhi kepercayaan pemerintah Filipina. Indonesia juga dianggap sebagai mediator yang ideal karena adil dan netral untuk memulihkan kembali stabilitas kawasan ASEAN sehingga mempercepat pembangunan ekonomi, politik, dan sosial budaya di kawasan.

Seminggu pasca penandatanganan perjanjian tersebut, pada bulan September dilaksanakan pemilu untuk memilih kepala daerah Authono- 
mous Region of Muslim Mindanao (ARMM) dan terpilihlah Nur Misuari sebagai Gubernur ARMM. Setelah itu, banyak kegiatan peningkatan kualitas administratif pemerintah daerah otonomi ini, salah satunya pembentukan Kantor Urusan Muslim sebagai badan yang siap tanggap dan mengawasi kebutuhan masyarakat Muslim di Filipina Selatan. Keterlibatan Indonesia dalam upaya penyelesaian masalah ini menunjukan adanya perubahan yang membawa perkembangan menuju perdamaian di Filipina Selatan.

Berdasarkan perkembangan konflik yang terjadi di Filipina Selatan 10 tahun terakhir ini, terlihat bahwa konflik yang terjadi sekarang dengan konflik yang terjadi sebelumnya menunjukan adanya kemiripan dan konflik cenderung lebih kompleks, karena adanya pengaruh dan peran dari pihak lain yang melakukan tindakan serupa yang merupakan sebuah awal dari konflik. Ketika kelompok pemberontak yang ada di Filipina terdesak oleh kekuatan pemerintah Filipina maka dengan adanya pihak luar yang menjadi musuh dari pemerintah Filipina juga. Sebut saja ISIS yang menjadi wadah bagi para pemberontak di wilayah Filipina Selatan untuk mendapatkan kekuatan deterence yang mampu membuat mereka bertahan dari serangan pemerintah Filipina.

Seiring berjalannya waktu, konflik yang ada di Filipina Selatan juga mengalami perubahan. Hal ini adalah bukti bahwa walaupun konflik dengan MNLF telah mendapatkan perjanjian perdamaian, namun perjanjian tersebut tidak berdampak bagi bekas anggota MNLF yang bisa saja menggalang kekuatan kecil untuk kembali melawan pemerintah. Adapun kelompok-kelompok yang terbilang kecil tersebut telah menjadi kelompok pemberontak dengan kekuatan yang mematikan contohnya seperti kelompok Abu Sayyaf yang 10 tahun terakhir ini terus menebar teror di Filipina Selatan.

\section{Kesimpulan}

Sesuai dengan kerangka berpikir Weberian, konflik di Filipina Selatan dan upaya Indonesia untuk menyelesaikannya adalah hasil dari interaksi sosial. Indonesia sebagai negara tetangga dan bagian dari ASEAN memandang bahwa penyelesaian konflik harus terjadi dengan secara win win solution sehingga tidak ada pihak yang dirugikan. Upaya Indonesia terwujud dalam Final Peace Agreement 1996 yang berisi perjanjian perdamaian dan kelanjutan dari Perjanjian Tripoli. Dalam upaya menyelesaikan konflik ini, Indonesia menjadi aktor perdamaian yang menjalankan strategi perdamaian dengan hubungan politik dan menunjukan konsistensinya sesuai dengan Pembukaan Undang-undang 1945 serta sikap penghormatan terhadap kedaulatan Filipina serta berupaya bersikap adil dan netral selama menjadi mediator konflik. Tulisan ini hanya ingin mendeskripsikan peran Indonesia dalam upaya penyelesaian konflik antara Filipina dan MNLF. 


\section{Daftar Pustaka}

Abdullah, T. dkk (1983) Tradisi dan Kebangkitan Islam di Asia Tenggara. Jakarta: LP3ES.

Chaidar, A. (1999) Wacana Ideologi Negara Islam Studi Harakah Darul Islam dan Moro National Liberation Front. Jakarta: Darul Falah.

Dardiri. dkk (2006) Sejarah Islam Asia Tenggara. Riau: Institute for Southeast Asian Islamic Studies.

Eldridge, J.E.T. (1980) Max Weber the Interpretation of Social Reality. New York: Shoken Books.

Firmanzah, F. (2017) ‘Dinamika Gerakan Pembebasan Muslim Moro di Filipina Selatan: Studi Terhadap Moro National Liberation Front (1971-1996)'. Intelektualita, 6(1): 29-50.

Gowing, P. (1979) Muslim Filipina: Hartage dan Horizon. Qeuzon: New Day. Majul, C.A. (1990) Dinamika Muslim Filipina. Jakarta: LP3ES.

Miall, R. and Haouse, W. (2000) Resolusi Damai Konflik Kontemporer, terj. Satrio, Jakarta: Raja Grapindo Persada.

Mubarok, Z. (1993) Geneologi Islam Radikal di Indonesia: Gerakan Pemikiran dan Prospek Demokrasi. Jakarta: LP3ES.

Mudler, N. (2005) Wacana Publik Asia Tenggara. Yogyakarta: Kanisius.

Rachmatsyah, B. (2016) Dinamika Politik Islam di Asia Tenggara: Peran Indonesia dalam Perdamaian MNLF dengan Filipina. Skripsi. Universitas Islam Negeri Syarif Hidayatulah Jakarta.

Steinberg, D. J. (1990). The Pilippines: a Singular and a Plural Place. Boulder: Westview Press.

Suryadinata, L. (1998) Politik Luar Negeri Indonesia Selama Orde Baru: Munculnya Militer. Jakarta: LP3ES.

Turner, J. (1991) The Structure of Sociological Theory. Belmont, CA: Wardworth Publising

Wurfel, D. (1991) Filipino Politics. Ithaca: Cornell University Press.

Yatim, B. (1985) Sukarno, Islam dan Nasionalisme. Jakarta: Inti Sarana Aksara. 